This document was prepared in conjunction with work accomplished under Contract No. DE-AC09-96SR18500 with the U.S. Department of Energy.

This work was prepared under an agreement with and funded by the U.S. Government. Neither the U. S. Government or its employees, nor any of its contractors, subcontractors or their employees, makes any express or implied: 1 . warranty or assumes any legal liability for the accuracy, completeness, or for the use or results of such use of any information, product, or process disclosed; or 2 . representation that such use or results of such use would not infringe privately owned rights; or 3 . endorsement or recommendation of any specifically identified commercial product, process, or service. Any views and opinions of authors expressed in this work do not necessarily state or reflect those of the United States Government, or its contractors, or subcontractors. 


\section{Glass Formulation Development to Support Melter Testing to Demonstrate Enhanced High Level Waste Throughput}

James C. Marra, Kevin M. Fox, David K. Peeler, Thomas B. Edwards, Amanda L. Youchak, James H. Gillam, Jr., John D. Vienna ${ }^{1}$, Sergey V. Stefanovsky ${ }^{2}$, and Albert S. Aloy ${ }^{3}$

Savannah River National Laboratory, Aiken, SC, U.S.A.

${ }^{1}$ Pacific Northwest National Laboratory, Richland, WA, U.S.A.; ${ }^{2}$ SIA Radon Institute, Moscow, Russia; ${ }^{3}$ V. G. Khlopin Radium Institute, St. Petersburg, Russia

\section{ABSTRACT}

The U.S. Department of Energy (DOE) is currently processing high-level waste (HLW) through a Joule-heated melter (JHM) at the Savannah River Site (SRS) and plans to vitrify HLW and Low activity waste (LAW) at the Hanford Site. Over the past few years at the DWPF, work has concentrated on increasing waste throughput. These efforts are continuing with an emphasis on high alumina content feeds. High alumina feeds have presented specific challenges for the JHM technology regarding the ability to increase waste loading yet still maintain product quality and adequate throughput. Alternatively, vitrification technology innovations are also being investigated as a means to increase waste throughput. The Cold Crucible Induction Melter (CCIM) technology affords the opportunity for higher vitrification process temperatures as compared to the current reference JHM technology. Higher process temperatures may allow for higher waste loading and higher melt rate.

Glass formulation testing to support melter demonstration testing was recently completed. This testing was specifically aimed at high alumina concentration wastes. Glass composition property models were utilized as a guide for formulation development. Both CCIM and JHM testing will be conducted so glass formulation testing was targeted at both technologies with a goal to significantly increase waste loading without compromising product quality.

\section{INTRODUCTION}

Vitrification of high level defense wastes has been underway in the United States since the mid 1990s with operations at the Defense Waste Processing Facility (DWPF) at the Savannah River Site. A recent focus of these operations is on increasing waste throughput. To achieve higher waste throughputs, both improvements in waste loading and increases in melt rate have been targeted [1]. Glass composition development efforts have resulted in increases in waste loading from nominally $28 \mathrm{wt} \%$ to about $40 \mathrm{wt} \%$. Glass formulation efforts have also resulted in frits that promote higher melt rates. Melter system enhancements such as the incorporation of a melter glass pump have also increased melter production rates. Construction is also underway on the Waste Treatment Plant (WTP) at the Hanford Site for facilities to vitrify high level and low activity radioactive wastes [2].

Future waste compositions, however, will present challenges to continued process improvements. Specifically, DWPF waste compositions with high alumina concentrations have been shown to limit waste loading [3]. High concentrations of alumina in alkali borosilicate glasses result in an increase potential for nepheline $\left(\mathrm{NaAlSiO}_{4}\right)$ crystal formation in the glass [3]. The formation of nepheline can have a detrimental impact on glass durability because it 
decreases the amount of the glass forming oxides $\mathrm{Al}_{2} \mathrm{O}_{3}$ and $\mathrm{SiO}_{2}$ in the glass matrix. Additionally, the refractory nature of alumina limits the melt rate for high alumina content feeds. Future processing at the WTP will also be impacted by high alumina content feeds [2].

The reference $\mathrm{JHM}$ technology has a maximum process temperature of $1150^{\circ} \mathrm{C}$. This temperature limitation combined with the refractory nature of the high alumina feeds hampers continued waste throughput improvements in JHMs. The CCIM technology offers the potential for higher vitrification process temperatures and increased waste loading for high alumina feeds.

A focused testing program is in progress with a primary goal to demonstrate maximized alumina content without detrimentally impacting glass properties or melter processing. The test program involves two phases: a glass composition testing phase and melter testing phase. Two approaches were utilized in the glass formulation testing effort. The first involved utilization of the positive attributes of the CCIM and formulating glasses specifically for processing at the higher process temperatures afforded by the CCIM. The second approach involved more detailed formulation and testing of glasses to evaluate compositional effects on glass properties. The results of this testing will be used to direct JHM testing on high content alumina glass compositions.

\section{EXPERIMENTAL DETAILS}

\section{Glass models}

Glass composition models have been utilized extensively as prediction tools for waste glass formulation and for control of vitrification processes [4-6]. A Product Composition Control System (PCCS) was developed for DWPF based on work by Jantzen, et al. [6]. A Measurement Acceptability Region (MAR) approach was developed by Peeler and Edwards to facilitate formulation of waste glasses for DWPF [7]. The MAR approach allows for efficient evaluation of glass compositions against the PCCS constraints for various glass quality and processing properties. A "nepheline discriminator" is included as one of the MAR terms. The nepheline discriminator is based on work by Li, et al. [8]. The nepheline discriminator utilizes waste glass composition to predict the potential for nepheline formation. Specifically, glasses with $\mathrm{SiO}_{2} /\left(\mathrm{SiO}_{2}+\mathrm{Na}_{2} \mathrm{O}+\mathrm{Al}_{2} \mathrm{O}_{3}\right)>0.62$, where the chemical formula represents mass fractions in the glass, do not tend to precipitate nepheline. The MAR approach was utilized in the formulation efforts in this study with specific emphasis on the nepheline discriminator function.

\section{Glass formulation development for CCIM testing}

As previously mentioned, the CCIM technology allows for processing at higher temperatures as compared to the JHM. Therefore, candidate glass compositions for CCIM testing at the SIA Radon Institute in Russia were targeted for melting temperatures of $1250^{\circ} \mathrm{C}$ and the MAR constraint for liquidus temperature (associated with processing in the JHM) was essentially ignored. A DWPF Sludge Batch 4 (SB4) surrogate waste composition was identified for testing (Table I). This sludge had a high alumina content and was previously found to present waste loading and melt rate challenges for the JHM.

A previously developed frit composition (Frit 503) was used as a basis for identification of candidate glass formulations. Frit 503 was modified by lowering the sodium content and/or increasing the boron content. It was hypothesized that removing sodium from the glass would 
mitigate nepheline formation based on the nepheline discriminator equation. A decrease in alkali content would also result in an increase in $\mathrm{SiO}_{2}$ content and would be expected to be favorable per the nepheline discriminator equation. Increasing boron content was also postulated to reduce nepheline formation based on previous observations [8]. The candidate frit compositions are shown in Table II. The MAR assessment tool was used to evaluate the compositions for waste loadings from 30 to $65 \mathrm{wt} \%$ waste loading (on a calcined oxide basis). Based on favorable MAR assessment results, it was decided to fabricate glasses using all five candidate frit compositions at 40, 45, 50, and $55 \mathrm{wt} \%$ waste loading. The compositions were batched using oxide chemicals and melted at $1250^{\circ} \mathrm{C}$ in $\mathrm{Pt} / \mathrm{Rh}$ crucibles. After nominally two hours at temperature, the glasses were quenched by pouring on a steel plate. A portion of the glass was heat treated to simulate cooling along the centerline of the DWPF canister (i.e. Canister Centerline Cooling (CCC) profile) [9]. Both quenched and CCC glass samples were then evaluated for crystallization using X-ray diffraction (XRD). Durability testing was conducted on quenched and CCC glass samples using the Product Consistency Test (PCT) [10].

\section{Glass formulation development for JHM testing}

A two-phased approach was used to develop glass compositions to support future JHM testing at the V. G. Khlopin Radium Institute (KRI) in Russia. The initial phase involved development of a test matrix of glasses to evaluate the solubility of aluminum, chromium and sulfur over a range of compositions that were considered bounding for future sludge batches to be processed through DWPF and WTP. A total of 45 glass compositions were developed. The 45 glasses were divided into a "U.S. matrix" for glass fabrication and analysis at the Savannah River National Laboratory (SRNL) and the Pacific Northwest National Laboratory (PNNL) and a "KRI matrix" for glass fabrication and testing at KRI. Details on these glass compositions are described elsewhere [11]. The results of this testing was used to direct glass composition development for future melter testing at KRI. The future melter testing will include small-scale melter testing to evaluate melt rate followed by testing in a larger-scaled JHM. To support DWPF needs, a sludge batch 5 (SB5) simulant composition was identified for testing. Two possible cases are under consideration for SB5 processing at DWPF. One involves typical tank blending and washing strategies to produce a suitable feed for processing in the DWPF. The second involves an additional process where aluminum is dissolved and removed from the sludge in order to reduce the mass of material that must be processed through the DWPF. Table I shows compositions for both scenarios. To support Hanford WTP interests, a high alumina sludge surrogate was selected for future melter testing (Table I).

Development of the specific glasses for subsequent melter testing was based in part on the results of the first portion of this study (i.e., the "U.S. Matrix" and "KRI Matrix" glasses) and leveraging existing data that may support the development process. In fact, the frit composition identified for melter testing to support WTP (Table II) was based on these previous studies and, for brevity, will not be discussed further. Candidate glasses for JHM testing were assessed using the MAR assessment tool for an array of frit formulations and the two SB5 compositions identified in Table I for varying waste loadings. This screening assessment led to 4 primary frit formulations for more detailed assessment. Test glasses based on these 4 frit formulations were fabricated at 35 and $40 \mathrm{wt} \%$ waste loading (calcined oxide basis) were melted at $1150^{\circ} \mathrm{C}$ for nominally 2 hours and poured on a steel plate. Both as-fabricated and CCC glasses were characterized as described previously. 


\section{RESULTS AND DISCUSSION}

\section{$\underline{\text { MAR assessment for CCIM glasses }}$}

A MAR assessment for SB4 candidate glasses for testing in the CCIM was conducted for waste loadings from 30 to $65 \mathrm{wt} \%$. The candidate compositions failed the current liquidus temperature constraint for $\mathrm{JHM}$ melter processing $\left(950^{\circ} \mathrm{C}\right)$ at all but the lowest waste loadings. As mentioned, this constraint was ignored due to the ability of the CCIM to achieve high process temperatures. When ignoring the liquidus constraint, the constraints that limited waste loading were "high viscosity" at low waste loadings and the "nepheline discriminator" at high waste loadings. The MAR acceptability regions for the 5 candidate frits are summarized in Table III.

\section{MAR assessment for DWPF JHM glasses}

MAR assessments were performed using the two sludge compositions, described earlier, along with the candidate frit compositions. In general, the ranges of WLs over which an acceptable glass was predicted were larger for the SB5 "without Al-dissolution" sludge composition. All of the selected frits provided WLs of $40 \%$ or better for this sludge. The WLs are all limited by predictions of nepheline crystallization. Frit 503 was also limited by a predicted liquidus temperature of more than $950^{\circ} \mathrm{C}$ at a WL of $42 \%$. The range of WLs over which an acceptable glass was predicted was smaller for the frits with the SB5 "with Aldissolution" sludge composition. The WL ranges were limited by either predictions of high liquidus temperature, low viscosity, or both. The MAR acceptability region for these candidate frits for the two sludge processing conditions is depicted in Table IV.

\section{Experimental results for CCIM candidate glasses}

Samples evaluated by XRD were analyzed under conditions providing a detection limit of approximately $0.5 \mathrm{vol} \%$. The XRD results for the quenched CCIM candidate glasses showed only the presence of spinel-type crystals (magnetite and trevorite) at the highest waste loading (55 wt \%). Spinel-type crystals were evident in the CCC glasses for all waste loadings. Nepheline was detected in CCC glasses at $55 \mathrm{wt} \%$ waste loading for compositions 503-R1, 503R2, 503-R3, and 503-R5. Nepheline was not found in any glasses for the 503-R4 composition. This was contradictory to the MAR assessment of predicted nepheline formation at $52 \mathrm{wt} \%$ waste loading.

The PCT results for the 50 and $55 \mathrm{wt} \%$ waste loading glasses are shown in Table V. The normalized release values were all significantly below the Environmental Assessment (EA) glass. The EA glass is the reference standard used to assess repository acceptability of the waste glass. An increase in relative release rate was evident for the $55 \mathrm{wt} \% \mathrm{CCC}$ glasses likely caused by the presence of nepheline in these glasses.

Based on the results of the experimental testing composition 503-R4 was selected for follow-on CCIM testing with the SB4 composition. This composition exhibited more than adequate durability and no evidence of nepheline formation occurred in $55 \mathrm{wt} \%$ waste loading glasses even after being subjected to the CCC heat treatment. 
Table I. Surrogate sludge compositions identified for testing.

\begin{tabular}{|c|c|c|c|c|}
\hline Oxide & SB4 & $\begin{array}{c}\text { SB5 w/o } \\
\text { Al- } \\
\text { dissolution }\end{array}$ & $\begin{array}{c}\text { SB5 w/ } \\
\text { Al-dissolution }\end{array}$ & $\begin{array}{c}\text { Hanford High } \\
\text { Alumina }\end{array}$ \\
\hline $\mathrm{Al}_{2} \mathrm{O}_{3}$ & 28.03 & 33.25 & 16.62 & 53.27 \\
\hline $\mathrm{CaO}$ & 3.04 & 2.09 & 2.92 & 2.39 \\
\hline $\mathrm{Cr}_{2} \mathrm{O}_{3}$ & 0.22 & 0.20 & 0.28 & 1.16 \\
\hline $\mathrm{Fe}_{2} \mathrm{O}_{3}$ & 31.89 & 26.42 & 36.85 & 13.11 \\
\hline $\mathrm{K}_{2} \mathrm{O}$ & 0.07 & 0.16 & 0.22 & 0.32 \\
\hline $\mathrm{MnO}$ & 6.36 & 5.20 & 7.25 & -- \\
\hline $\mathrm{Na}_{2} \mathrm{O}$ & 20.57 & 24.62 & 24.62 & 7.96 \\
\hline $\mathrm{NiO}$ & 1.82 & 2.31 & 3.22 & 0.89 \\
\hline $\mathrm{SiO}_{2}$ & 2.98 & 1.82 & 2.54 & 10.88 \\
\hline $\mathrm{TiO}_{2}$ & 0.04 & 0.52 & 0.72 & 0.02 \\
\hline $\mathrm{ZnO}$ & 0.05 & 0.07 & 0.10 & 0.18 \\
\hline $\mathrm{ZrO}_{2}$ & 0.10 & 0.23 & 0.32 & 0.88 \\
\hline $\mathrm{BaO}$ & 0.08 & 0.11 & 0.15 & 0.12 \\
\hline $\mathrm{Ce}_{2} \mathrm{O}_{3}$ & 0.24 & 0.23 & 0.32 & -- \\
\hline $\mathrm{CuO}$ & 0.06 & 0.07 & 0.10 & -- \\
\hline $\mathrm{La}_{2} \mathrm{O}_{3}$ & 0.03 & 0.03 & 0.04 & -- \\
\hline $\mathrm{MgO}$ & 3.05 & 1.41 & 1.97 & 0.26 \\
\hline $\mathrm{PbO}$ & 0.42 & 0.10 & 0.14 & 0.91 \\
\hline $\mathrm{SO}_{4}{ }^{2-}$ & 0.95 & 1.16 & 1.62 & 0.44 \\
\hline $\mathrm{B}_{2} \mathrm{O}_{3}$ & -- & -- & -- & 0.42 \\
\hline $\mathrm{Bi}_{2} \mathrm{O}_{3}$ & -- & -- & -- & 2.54 \\
\hline $\mathrm{CdO}$ & -- & -- & -- & 0.05 \\
\hline $\mathrm{Li}_{2} \mathrm{O}$ & -- & -- & -- & 0.38 \\
\hline $\mathrm{P} 2 \mathrm{O} 5$ & -- & -- & -- & 2.34 \\
\hline$F$ & -- & -- & -- & 1.48 \\
\hline Total & 100.00 & 100.00 & 100.00 & 100.00 \\
\hline
\end{tabular}

Table II. Candidate frit formulations for melter testing (oxide concentrations in wt \%).

\begin{tabular}{|c|c|c|c|c|c|c|c|c|}
\hline $\begin{array}{l}\text { Melter } \\
\text { Testing }\end{array}$ & Frit ID & $\mathbf{B}_{2} \mathbf{O}_{3}$ & $\mathrm{CaO}$ & $\mathbf{L i}_{2} \mathbf{O}$ & $\mathrm{Na}_{2} \mathrm{O}$ & $\mathbf{K}_{2} \mathbf{O}$ & $\mathrm{SiO}_{2}$ & Total \\
\hline \multirow[t]{5}{*}{ CCIM } & 503-R1 & 14.0 & -- & 8.0 & 2.0 & -- & 76.0 & 100.0 \\
\hline & 503-R2 & 14.0 & -- & 8.0 & -- & -- & 78.0 & 100.0 \\
\hline & 503-R3 & 16.0 & -- & 8.0 & 2.0 & -- & 74.0 & 100.0 \\
\hline & 503-R4 & 16.0 & -- & 8.0 & -- & -- & 74.0 & 100.0 \\
\hline & 503-R5 & 18.0 & -- & 8.0 & -- & -- & 74.0 & 100.0 \\
\hline \multirow{4}{*}{$\begin{array}{c}\text { JHM } \\
\text { (DWPF) }\end{array}$} & 503 & 14.0 & -- & 8.0 & 4.0 & -- & 74.0 & 100.0 \\
\hline & 517 & 17.0 & -- & 10.0 & 3.0 & -- & 70.0 & 100.0 \\
\hline & 520 & 8.0 & 1.0 & 10.0 & 4.0 & -- & 77.0 & 100.0 \\
\hline & 521 & 10.0 & 1.0 & 8.0 & 6.0 & -- & 75.0 & 100.0 \\
\hline $\begin{array}{c}\text { JHM } \\
\text { (WTP) }\end{array}$ & HAL-17 & 31.0 & 12.0 & 7.4 & 4.3 & 5.0 & 40.3 & 100.0 \\
\hline
\end{tabular}


Table III. MAR assessment for candidate glasses for CCIM testing.

\begin{tabular}{|c|c|c|}
\hline \multirow{2}{*}{ Frit ID } & \multicolumn{2}{|c|}{ SB4 } \\
\cline { 2 - 3 } & $\begin{array}{c}\text { WL Range } \\
\text { (wt \%) }\end{array}$ & Limiting Model \\
\hline 503-R1 & $34-49$ & High $\eta$, Neph \\
\hline 503-R2 & $42-51$ & High $\eta$, Neph \\
\hline $503-R 3$ & $30-49$ & Neph \\
\hline 503-R4 & $37-51$ & High $\eta$, Neph \\
\hline 503-R5 & $33-50$ & High $\eta$, Neph \\
\hline
\end{tabular}

Table IV. MAR assessement for candidate glasses for JHM testing to support DWPF.

\begin{tabular}{|c|c|c|c|c||}
\hline \multirow{3}{*}{ Frit ID } & \multicolumn{2}{|c|}{ SB5 w/o Al-dissolution } & \multicolumn{2}{c|}{ SB5 w/ Al-dissolution } \\
\cline { 2 - 5 } & $\begin{array}{c}\text { WL Range } \\
\text { (wt \%) }\end{array}$ & $\begin{array}{c}\text { Limiting } \\
\text { Model }\end{array}$ & $\begin{array}{c}\text { WL Range } \\
\text { (wt \%) }\end{array}$ & $\begin{array}{c}\text { Limiting } \\
\text { Model }\end{array}$ \\
\hline 503 & $26-41$ & $\mathrm{~T}_{\mathrm{L}}$, Neph & $26-36$ & $\mathrm{~T}_{\mathrm{L}}$ \\
\hline 517 & $26-40$ & $\mathrm{Neph}$ & $26-28$ & Low $\eta$ \\
\hline 520 & $25-42$ & $\mathrm{Neph}$ & $25-39$ & $\mathrm{~T}_{\mathrm{L}}$, Low $\eta$ \\
\hline 521 & $25-40$ & Neph & $25-39$ & $\mathrm{~T}_{\mathrm{L}}$, Low $\eta$ \\
\hline
\end{tabular}

\section{$\underline{\text { Experimental results for JHM candidate glasses }}$}

In general, all of the quenched glasses (both 35 and $40 \mathrm{wt} \%$ waste loading) were either X-ray amorphous (no crystallization at the XRD detection limit) or contained small amounts of magnetite and/or trevorite. XRD results for the ccc glasses were similar to those for the quenched glasses, although all of the ccc glasses at $40 \%$ waste loading were found to contain trevorite. It is noted that nepheline formation was not identified in any of the study glasses up to $40 \mathrm{wt} \%$ waste loading, consistent with the nepheline discriminator constraint that was included in the MAR assessments.

The PCT results for the $50 \mathrm{wt} \%$ waste loading (Table VI) show that each glass has a durability that is considered very acceptable, with normalized releases for boron (NL [B] in g/L) that are better than an order of magnitude below that of the EA glass standard, regardless of heat treatment.

Because the crystallization and PCT data were comparable for all frit compositions, the selection was made with the intent of better determining the effect of frit composition on melt rate. Recent frit development efforts for DWPF have identified frits with a higher concentration of $\mathrm{B}_{2} \mathrm{O}_{3}$ as being beneficial for improving melt rate [12]. Frits 520, 503 and 517 were therefore recommended for the initial melter testing since they cover a relatively wide range of $\mathrm{B}_{2} \mathrm{O}_{3}$ concentrations $(8,14$ and $17 \mathrm{wt} \%$, respectively). This selection of frits also eliminates the frit that resulted in the poorest normalized release for boron seen in this study $(1.32 \mathrm{~g} / \mathrm{L}$ for Frit 521 at $40 \%$ waste loading with the SB5 without Al-dissolution sludge). 
Table V. Product Consistency Test Results for CCIM candidate glasses at 50 and $55 \mathrm{wt} \%$ waste loading.

\begin{tabular}{|c|c|c|c|c|c|}
\hline \multirow[b]{2}{*}{ Glass ID } & \multirow[b]{2}{*}{ Waste Loading } & \multicolumn{4}{|c|}{ Normalized Release (g/L) } \\
\hline & & $\mathbf{B}$ & $\mathbf{L i}$ & $\mathbf{N a}$ & $\mathbf{S i}$ \\
\hline \multirow[t]{2}{*}{$503-\mathrm{R} 1$} & 50 & 0.62 & 0.70 & 0.60 & 0.37 \\
\hline & 55 & 0.48 & 0.60 & 0.60 & 0.37 \\
\hline \multirow[t]{2}{*}{ 503-R1 CCC } & 50 & 0.35 & 0.47 & 0.38 & 0.28 \\
\hline & 55 & 0.84 & 0.92 & 0.64 & 0.34 \\
\hline \multirow[t]{2}{*}{ 503-R2 } & 50 & 0.56 & 0.68 & 0.52 & 0.35 \\
\hline & 55 & 0.45 & 0.59 & 0.53 & 0.36 \\
\hline \multirow[t]{2}{*}{ 503-R2-CCC } & 50 & 0.32 & 0.48 & 0.34 & 0.28 \\
\hline & 55 & 0.53 & 0.68 & 0.45 & 0.27 \\
\hline \multirow[t]{2}{*}{$503-\mathrm{R} 3$} & 50 & 0.65 & 0.72 & 0.63 & 0.36 \\
\hline & 55 & 0.47 & 0.58 & 0.59 & 0.37 \\
\hline \multirow[t]{2}{*}{ 503-R3 CCC } & 50 & 0.40 & 0.52 & 0.44 & 0.31 \\
\hline & 55 & 0.87 & 0.93 & 0.65 & 0.34 \\
\hline \multirow[t]{2}{*}{ 503-R4 } & 50 & 0.55 & 0.68 & 0.53 & 0.34 \\
\hline & 55 & 0.42 & 0.56 & 0.53 & 0.34 \\
\hline \multirow[t]{2}{*}{ 503-R4 CCC } & 50 & 0.33 & 0.48 & 0.34 & 0.28 \\
\hline & 55 & 0.59 & 0.75 & 0.49 & 0.32 \\
\hline \multirow[t]{2}{*}{ 503-R5 } & 50 & 0.61 & 0.71 & 0.55 & 0.35 \\
\hline & 55 & 0.47 & 0.58 & 0.54 & 0.35 \\
\hline \multirow[t]{2}{*}{ 503-R5 CCC } & 50 & 0.35 & 0.48 & 0.35 & 0.28 \\
\hline & 55 & 0.49 & 0.67 & 0.44 & 0.28 \\
\hline EA & & 18.11 & 9.99 & 13.78 & 4.04 \\
\hline
\end{tabular}

Table VI. Product Consistency Test Results for JHM candidate glasses at $40 \mathrm{wt} \%$ waste loading.

\begin{tabular}{|c|c|c|c|c|c|c|c|}
\hline $\begin{array}{l}\text { Frit } \\
\text { ID }\end{array}$ & $\begin{array}{l}\text { Sludge } \\
\text { Type }\end{array}$ & WL & $\begin{array}{c}\text { Heat } \\
\text { Treatment }\end{array}$ & $\begin{array}{c}\text { NL [Li] } \\
(g / L)\end{array}$ & $\begin{array}{l}\text { NL [B] } \\
(\mathrm{g} / \mathrm{L})\end{array}$ & $\begin{array}{c}\text { NL [Na] } \\
(\mathrm{g} / \mathrm{L})\end{array}$ & $\begin{array}{c}\text { NL [Si] } \\
(\mathrm{g} / \mathrm{L})\end{array}$ \\
\hline \multirow{2}{*}{520} & \multirow{8}{*}{ 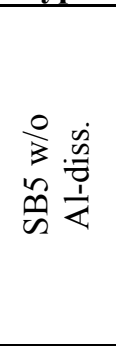 } & \multirow{16}{*}{$40 \%$} & quenched & 0.67 & 0.60 & 0.69 & 0.42 \\
\hline & & & $\mathrm{ccc}$ & 1.14 & 1.02 & 0.85 & 0.55 \\
\hline \multirow{2}{*}{503} & & & quenched & 0.65 & 0.55 & 0.57 & 0.40 \\
\hline & & & $\mathrm{ccc}$ & 0.62 & 0.52 & 0.56 & 0.39 \\
\hline \multirow{2}{*}{517} & & & quenched & 0.66 & 0.69 & 0.62 & 0.43 \\
\hline & & & $\mathrm{ccc}$ & 0.66 & 0.66 & 0.60 & 0.43 \\
\hline \multirow{2}{*}{521} & & & quenched & 0.58 & 0.56 & 0.64 & 0.38 \\
\hline & & & $\mathrm{ccc}$ & 1.19 & 1.32 & 0.92 & 0.51 \\
\hline \multirow{2}{*}{520} & \multirow{8}{*}{ 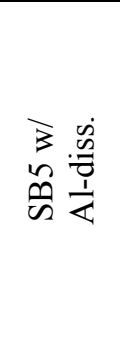 } & & quenched & 1.02 & 1.13 & 1.21 & 0.62 \\
\hline & & & $\mathrm{ccc}$ & 1.16 & 1.15 & 1.20 & 0.67 \\
\hline \multirow{2}{*}{503} & & & quenched & 0.80 & 0.85 & 0.88 & 0.48 \\
\hline & & & $\mathrm{ccc}$ & 0.82 & 0.86 & 0.87 & 0.49 \\
\hline \multirow{2}{*}{517} & & & quenched & 1.01 & 1.13 & 1.11 & 0.56 \\
\hline & & & $\mathrm{ccc}$ & 1.10 & 1.18 & 1.15 & 0.61 \\
\hline \multirow{2}{*}{521} & & & quenched & 0.92 & 1.03 & 1.15 & 0.56 \\
\hline & & & $\mathrm{ccc}$ & 0.97 & 1.05 & 1.14 & 0.58 \\
\hline
\end{tabular}




\section{CONCLUSIONS}

The MAR assessment approach combined with experimental testing of select glasses proved to be successful in efficiently identifying glass composition for subsequent melter testing. A candidate frit (503-R4) for testing at $50 \mathrm{wt} \%$ waste loading was identified for testing in the CCIM. Three candidate frits (frits 503, 520 and 517) were identified for initial small-scale melter testing at KRI to evaluate melt rate. This initial testing will lead to selection of a preferred frit for follow-on larger-scale melter testing,

\section{REFERENCES}

1. M.E. Smith, A.B. Barnes, J.R. Coleman, R.C. Hopkins, D.C. Iverson, R.J. O'Driscoll and D.K. Peeler, "Recent Process and Equipment Improvements to Increase High Level Waste Throughput at the Defense Waste Processing Facility," MS\&T'06 Conference Proceedings, American Ceramic Society, Westerville, OH (2006).

2. J.M. Perez, S.M. Barnes, S. Kelly, L. Petkus and E.V. Morrey, "Vitrification Testing and Demonstration for the Hanford Waste Treatment Plant," Ceramic Transactions, Vol. 168, American Ceramic Society, Westerville, OH (2005).

3. D.K. Peeler, T.B. Edwards, D.R. Best, I.A. Reamer and R.J. Workman, "Nepheline Formation Study for Sludge Batch 4 (SB4): Phase 2 Experimental Results," WSRC-TR2006-00006, Washington Savannah River Company, Aiken, SC (2006).

4. P. Hrma, G.F. Piepel, J.D. Vienna, P.E. Redgate, M.J. Schweiger and D.E. Smith, "Prediction of Nuclear Waste Glass Dissolution as a Function of Composition," Ceramic Transactions, Vol. 61, American Ceramic Society, Westerville, OH (1995).

5. P.Hrma, G.F. Piepel, P.E. Redgate, D.E. Smith, M.J. Schweiger, J.D. Vienna and D.S. Kim, "Prediction of Processing Properties for Nuclear Waste Glasses," Ceramic Transactions, Vol. 61, American Ceramic Society, Westerville, OH (1995).

6. C.M. Jantzen, J.B. Pickett, K.G. Brown, T.B. Edwards and D.C. Beam, "Process/Product Models for the Defense Waste Processing Facility: Part I Prediciting Glass Durability from Composition Using a Thermodynamic Hydration Energy Reaction Model (THERMO)," WSRC-TR-93-672, Westinghouse Savannah River Company, Aiken, SC (1995).

7. D.K. Peeler and T.B. Edwards, "Frit Development for Sludge Batch 3," WSRC-TR-200200491, Westinghouse Savannah River Company, Aiken, SC (2002).

8. H. Li, P. Hrma, J.D. Vienna, M. Qian, Y. Su and D.E. Smith, "Effects of $\mathrm{Al}_{2} \mathrm{O}_{3}, \mathrm{~B}_{2} \mathrm{O}_{3}, \mathrm{Na}_{2} \mathrm{O}$, and $\mathrm{SiO}_{2}$ on Nepheline Formation in Borosilicate Glasses: Chemical and Physical Correlations, J. Non-Crystalline Solids, 331 (2003).

9. S. L. Marra and C. M. Jantzen, "Characterization of Projected DWPF Glass Heat Treated to Simulate Canister Centerline Cooling," WSRC-TR-92-142, Revision 1, Westinghouse Savannah River Company, Aiken, SC (1993).

10. "Standard Test Methods for Determining Chemical Durability of Nuclear Waste Glasses: The Product Consistency Test (PCT)," ASTM C-1285, (2002).

11 A. Aloy, J. D. Vienna, K. M. Fox, T. B. Edwards and D. K. Peeler, "Glass Selection Strategy: Development of US and KRI Test Matrices,” WSRC-STI-2006-00205, Washington Savannnah River Company, Aiken, SC (2006).

12. D.K. Peeler and T. B. Edwards, "High $\mathrm{B}_{2} \mathrm{O}_{3} / \mathrm{Fe}_{2} \mathrm{O}_{3}$-based Frits: MAR Assessments for Sludge Batch 4 (SB4)," WSRC-TR-2006-00181, Washington Savannah River Company, Aiken, SC (2006). 